\title{
Uji Aktivitas Antidiabetes Dengan Metode Penghambatan Enzim $\alpha$-Glukosidase dan Karakterisasi Kandungan Senyawa Aktif pada Fraksi Metanol dan Kloroform Daun Lavetar (Wedelia biflora (L).DC) Asal Biak
}

\author{
Bertha Mangallo ${ }^{1)}$, Adrianus Banu Pradana Putra ${ }^{1)}$, Maria Ludya Pulung 1) \\ Fakultas Matematika dan Ilmu Pengetahuan Alam, Universitas Papua \\ Jl. Gunung Salju, Manokwari Barat, Amaban, Manokwari, Kabupaten Manokwari, Papua Barat. 98314 \\ * Corresponding Authors E-Mail: b.mangallo@unipa.ac.id
}

\begin{abstract}
ABSTRAK
Salah satu jenis tanaman yang dijadikan sebagai obat tradisional adalah tumbuhan Lavetar ( $W$. biflora) yang di manfaatkan oleh masyarakat Biak sebagai obat untuk mengobati penyakit diabetes. Penemuan sumber penghambat $\alpha$-glukosidase sangat bermanfaat dalam upaya pengembangan obat herbal yang lebih efektif bagi penderita diabetes. Penelitian ini bertujuan untuk menentukan aktivitas antidiabetes fraksi metanol dan fraksi kloroform daun Lavetar dengan metode aktivitas penghambatan enzim $\alpha$-glukosidase serta menentukan kandungan senyawa aktif dengan menggunakan GCMS. Hasil skrining fitokimia menunjukkan bahwa senyawa aktif pada fraksi metanol adalah flavonoid dan tannin sedangkan fraksi kloroform mengandung senyawa flavonoid, tannin, dan saponin. Uji aktivitas penghambatan enzim $\alpha$-glukosidase fraksi kloroform tergolong lemah sedangkan fraksi metanol tergolong sangat lemah dengan nilai nilai $\mathrm{IC}_{50}$ masing - masing sebesar $112,562 \mu \mathrm{g} / \mathrm{mL}$ dan $211,151 \mu \mathrm{g} / \mathrm{mL}$. Hasil Interpretasi spektra FTIR dan skrining fitokimia menunjukkan bahwa gugus fungsi utama adalah flavanoid. Hasil analisis dengan GC-MS menunjukkan bahwa pada fraksi metanol terdapat 84 puncak senyawa dengan senyawa dominan yaitu 1 -Heptatriacotanol $(\mathrm{m} / \mathrm{z}=190)$ dan fraksi kloroform terdapat 102 puncak senyawa dengan senyawa dominan yaitu cyclopropanebutanoic acid,2-[[2-[[2-[(2pentylcyclopropyl)methyl]cyclopropyl]metyl]-, metyl ester $(\mathrm{m} / \mathrm{z}=270)$.
\end{abstract}

Kata Kunci : Antidiabetes, fraksi kloroform, fraksi metanol, $\alpha$-glukosidase, Wedelia biflora. 


\section{PENDAHULUAN}

Diabetes melitus adalah suatu penyakit hiperglikemia yang bercirikan kekurangan insulin secara mutlak atau penurunan kepekaan sel terhadap insulin (Corwin, 2000). Diabetes melitus menjadi permasalahan kesehatan dunia karena tingginya morbiditas maupun mortalitas yang ditimbulkan oleh penyakit tersebut. Data World Health Organization (WHO, 2015) menunjukkan bahwa persentase orang dewasa penderita penyakit diabetes sebesar $8,5 \%$ atau sekitar 415 juta jiwa. Prevalensi penderita diabetes di Indonesia cenderung meningkat yaitu $5,7 \%$ (tahun 2007) menjadi 6,9\% (tahun 2013). Pada tahun 2015, Indonesia menempati peringkat ke tujuh untuk prevalensi penderita diabetes tertinggi di dunia bersama dengan Cina, India, Amerika Serikat, Brazil, Russia dan Meksiko (Anonim, 2016).

Meningkatnya prevalensi penyakit diabetes melitus dari tahun ke tahun menunjukkan perlunya perhatian serius dalam terapi penyakit tersebut. Kecenderungan masyarakat untuk melakukan pengobatan secara tradisional semakin meningkat, hal ini mendorong pencarian pengobatan untuk menemukan obat alternatif dengan efikasi yang lebih baik sehingga memungkinkan penderita diabetes mempunyai banyak pilihan pengobatan untuk meningkatkan peluang kesembuhan dan efek samping yang minimal serta biaya yang relatif lebih murah.

Indonesia merupakan Negara yang kaya akan tanaman obat yang berkhasiat untuk berbagai pengobatan. Biak merupakan salah satu daerah yang ada di Papua, yang umumnya masyarakat lokal daerah tersebut memanfaatkan tumbuhtumbuhan sebagai tanaman obat untuk berbagai macam penyakit. Salah satu jenis tanaman yang dijadikan sebagai obat tradisional adalah tumbuhan Lavetar $(W$. biflora) yang di manfaatkan oleh masyarakat Biak sebagai obat untuk mengobati penyakit diabetes. Pemanfaatannya dengan cara merebus bebrapa daun tumbuhan tersebut, kemudian air rebusan diminum. Penemuan sumber penghambat $\alpha$ glukosidase sangat bermanfaat dalam upaya pengembangan obat herbal yang lebih efektif bagi penderita diabetes. Penelitian ini bertujuan untuk menentukan aktivitas antidiabetes fraksi metanol dan fraksi kloroform daun Lavetar dengan metode aktivitas penghambatan enzim $\alpha$ glukosidase serta menentukan kandungan senyawa aktif dengan menggunakan GCMS.

\section{METODOLOGI PENELITIAN}

\section{Alat dan Bahan}

Alat-alat yang digunakan dalam penelitian ini adalah seperangkat alat-alat gelas, seperangkat alat Rotary Evaporator Evela N1000, oven model memmert 100 800, timbangan analitik, blender, penangas air, spektrofotometer FTIR dan GC-MS.

Bahan utama dalam penelitian ini adalah sampel daun Lavetar ( $W$. biflora). Bahan lainnya seperti aquades, metanol,kloroform,etil asetat, pereaksi Dragendroff, pereaksi mayer, reagen Wagner, kertas saring Whatman 40;42, $\mathrm{HCl}$ pekat, serbuk magnesium, eter, dan $\mathrm{FeCl}_{3} 1 \%$, dapar fosfat, $p$-nitrofenil- $\alpha$-Dglukopiranosida, natrium karbonat $\left(\mathrm{Na}_{2} \mathrm{CO}_{3}\right)$.

\section{Metode Penelitian \\ Pembuatan Ekstrak}

Sampel daun Lavetar yang telah dikeringkan dan dibuat dalam bentuk serbuk, diekstraksi dengan metode maserasi menggunakan pelarut methanol selama 3 kali 24 jam dengan perbandingan sampel dan pelarut 1:2,5 $(\mathrm{w} / \mathrm{v})$. Filtrat yang diperoleh diuapkan menggunakan rotary evaporator sampai diperoleh ekstrak kental. 


\section{Fraksinasi Secara Ekstraksi Cair-Cair (Partisi)}

Ekstrak kental metanol yang diperoleh kemudian diencerkan dengan metanol hingga volume $20 \mathrm{~mL}$. Kemudian difraksinasi secara cair-cair dengan kloroform hingga terbentuk dua lapisan. Fraksi metanol dan fraksi kloroform yang diperoleh, dipekatkan dan dilanjutkan dengan uji skrinning fitokimia dan karakterisasi dengan FTIR dan GC-MS.

\section{Uji Fitokimia}

Identifikasi kandungan kimia dalam ekstrak dilakukan terhadap senyawasenyawa kandungan metabolit sekunder golongan: flavonoid, alkaloid, saponin, dan tanin (Harborne, 1987).

\section{Uji Aktivitas Penghambatan Enzin $\alpha-$ glukosidase}

Uji aktivitas penghambatan enzim $\alpha$-Gkukosidase dilakukan untuk mengukur aktivitas anti hiperglikemik ekstrak. Dalam pengujian ini, enzim $\alpha-$ glukosidase akan menghidrolisis pnitrofenil- $\alpha$-D-glukopiranosid menjadi $\mathrm{p}$ nitrofenol yang berwarna kuning dan glukosa. Prosedur pengujian meliputi :

1. Penyiapan Reagen

a. Enzim alfa-glukosidase sebanyak $1,3 \mathrm{mg}$ dilarutkan dalam $50 \mathrm{ml}$ buffer fosfat $(\mathrm{pH} \mathrm{7,0)}$

b. Substrat p-nitrofenil $\alpha$ Dglukopiranosid $5 \mathrm{mM}$ dibuat dengan melarutkan $150 \mathrm{mg}$ substrat kedalam $100 \mathrm{ml}$ buffer fosfat $(\mathrm{pH}$ $7,0)$

c. Natrium karbonat $200 \mathrm{mM}$ dibuat dengan melarutkan 2,12 gram natrium karbonat dalam $100 \mathrm{ml}$ buffer fosfat/air

d. Buffer fosfat $\mathrm{pH} 7$

e. DMSO

2. Pengerjaan/Pencampuran

Sampel ditimbang $10 \mathrm{mg}$ ditambahkan 100-1000 mikro liter DMSO, disonikasi dengan sonikator hingga larut, ditambahkan buffer hingga $10 \mathrm{ml}$ sehingga didapatkan larutan stok 1000 ppm, selanjutnya dibuat seri pengenceran sebanyak 5 seri konsentrasi yakni 50 ppm, 100 ppm, 150 ppm, 200 ppm dan $250 \mathrm{ppm}$ dengan cara memipet larutan stok sebanyak $50 \mu \mathrm{L}, 100 \mu \mathrm{L}, 150$ $\mu \mathrm{L}, 200 \mu \mathrm{L}$ dan $250 \mu \mathrm{L}$ dari larutan stok 1000 ppm dan dicukupkan volumenya dengan buffer fosfat hingga $1000 \mu \mathrm{L}$.

Sampel sebanyak $60 \mu 1$ dimasukkan ke dalam well plate kemudian ditambahkan dengan $20 \mu \mathrm{l}$ p-nitrofenil $\alpha$ D-glukopiranosid $5 \mathrm{mM}$ sebagai substrat. Setelah dicampur, diinkubasi $37^{\circ} \mathrm{C}$ selama 5 menit, kemudian ditambahkan $20 \mu \mathrm{l}$ larutan enzim dan diinkubasi pada $37^{\circ} \mathrm{C}$ selama 5 menit. Reaksi enzimatik dihentikan dengan penambahan $100 \mu \mathrm{l}$ natrium karbonat $200 \mathrm{mM}$ dan $\mathrm{p}$ nitrofenol yang terbentuk diukur pada panjang gelombang $405 \mathrm{~nm}$.

Untuk $\mathrm{S}_{0}$ atau pengurang dari warna sampelnya dibuat dengan menambahkan $60 \mu \mathrm{L}$ sampel dari masingmasing konsentrasi, di tambahkan $40 \mu \mathrm{L}$ buffer dan di tambahkan $100 \mu \mathrm{L} \mathrm{Na}_{2} \mathrm{CO}_{3}$, diukur serapannya menggunakan Spektrofotometer ELIZA dengan panjang gelombang $405 \mathrm{~nm}$. Persentase penghambatan diukur dengan menggunakan persamaan: $\%$ Penghambatan $=[(\mathrm{C}-\mathrm{S}) / \mathrm{C}] \mathrm{x}$

$100 \% \ldots \ldots \ldots \ldots \ldots \ldots \ldots$ (1)

Keterangan :

$\mathrm{C}=$ Absorbansi kontrol negatif blanko kontrol negatif $\mathrm{S}=$ absorban ekstrak (selisih absorban ekstrak dengan enzim dan tanpa enzim)

Nilai $\mathrm{IC}_{50}$ dihitung dengan menggunakan persamaan regresi linier, konsentrasi sampel sebagai sumbu $\mathrm{x}$ dan $\%$ inhibisi sebagai sumbu y. Persamaan regresi $\mathrm{y}=$ $\mathrm{bx}+\mathrm{a}$ yang diperoleh, digunakan untuk menentukan $\mathrm{IC}_{50}$ dengan rumus pada persamaan 2 .

$$
\begin{aligned}
& I C_{50} \\
& =\frac{50-a}{b} \ldots \ldots \ldots \ldots \ldots \ldots \ldots \ldots \ldots \ldots \ldots \ldots
\end{aligned}
$$

\section{Karakterisasi dengan Spektroskopi FTIR dan GCMS}

Identifikasi gugus fungsi dalam fraksi metanol dan fraksi kloroform 
menggunakan spektrofotometer FTIR dan Penentuan berat molekul senyawa yang terdapat pada fraksi methanol dan fraksi kloroform menggunakan GCMS.

\section{HASIL DAN PEMBAHASAN}

\section{Ekstrak dan Fraksinasi Daun Lavetar (W. biflora)}

Ekstrak kental methanol daun Lavetar yang diperoleh berwarna hijau kehitaman dengan rendemen sebesar 5,02 $\%$. Ekstrak metanol kemudian dipartisi dengan pelarut kloroform sehingga terbentuk lapisan bifase. Senyawa aktif yang bersifat polar dan non polar masing- masing terdistribusi ke dalam pelarut methanol dan kloroform. Lapisan bawah merupakan fraksi kloroform berwarna hijau tua mengandung senyawa non polar dan lapisan atas merupakan fraksi metanol berwarna merah kecoklatan mengandung senyawa polar.

\section{Hasil Skrining Fitokimia Fraksi Hasil Partisi Cair-Cair}

Skrining fitokimia dilakukan untuk mengetahui kandungan senyawa metabolit sekunder yang terdapat di dalam tiap fraksi (Tabel 1).

Tabel 1. Skrining Fitokimia Daun Lavetar

\begin{tabular}{ccc}
\hline \multirow{2}{*}{ Uji Fitokimia } & \multicolumn{2}{c}{ Kraksi } \\
\cline { 2 - 3 } Kloroform & Metanol \\
\hline \multirow{2}{*}{ Alkaloid } & - & - \\
& Tidak terdapat endapan & Tidak terdapat endapan \\
\multirow{2}{*}{ Flavanoid } & +++ & +++ \\
& Kuning & Kuning \\
Tanin & + & + \\
& Sedikit endapan hitam & Sedikit endapan hitam \\
Saponin & + & - \\
& Terdapat sedikit busa dan & Tidak terdapat busa \\
\hline
\end{tabular}

$$
\begin{array}{rll}
\text { Keterangan : } & - & \text { : Negatif } \\
& + & \text { : Positif Lemah } \\
& ++ & \text { : Positif Sedang } \\
& ++ & \text { : Positif Kuat }
\end{array}
$$

Hasil uji skrining fitokimia menunjukkan bahwa fraksi methanol maupun fraksi kloroform positif kuat mengandung senyawa flavonoid, yang ditandai dengan terbentuknya warna kuning. Pada uji alkaloid, fraksi metanol dan fraksi kloroform menunjukkan hasil uji negative, sedangkan pada uji tanin, fraksi metanol dan fraksi kloroform menunjukkan hasil uji positif lemah yang ditandai dengan terbentuknya sedikit endapan hitam.
Pada uji Saponin, menunjukkan hasil positif lemah untuk fraksi kloroform dan hasil negatif untuk fraksi metanol.

\section{Analisis Gugus Fungsi Berdasarkan Spektrum IR}

Karakterisasi gugus fungsi fraksi metanol dan fraksi kloroform daun Lavetar menggunakan FTIR disajikan dalam Gambar 1. 


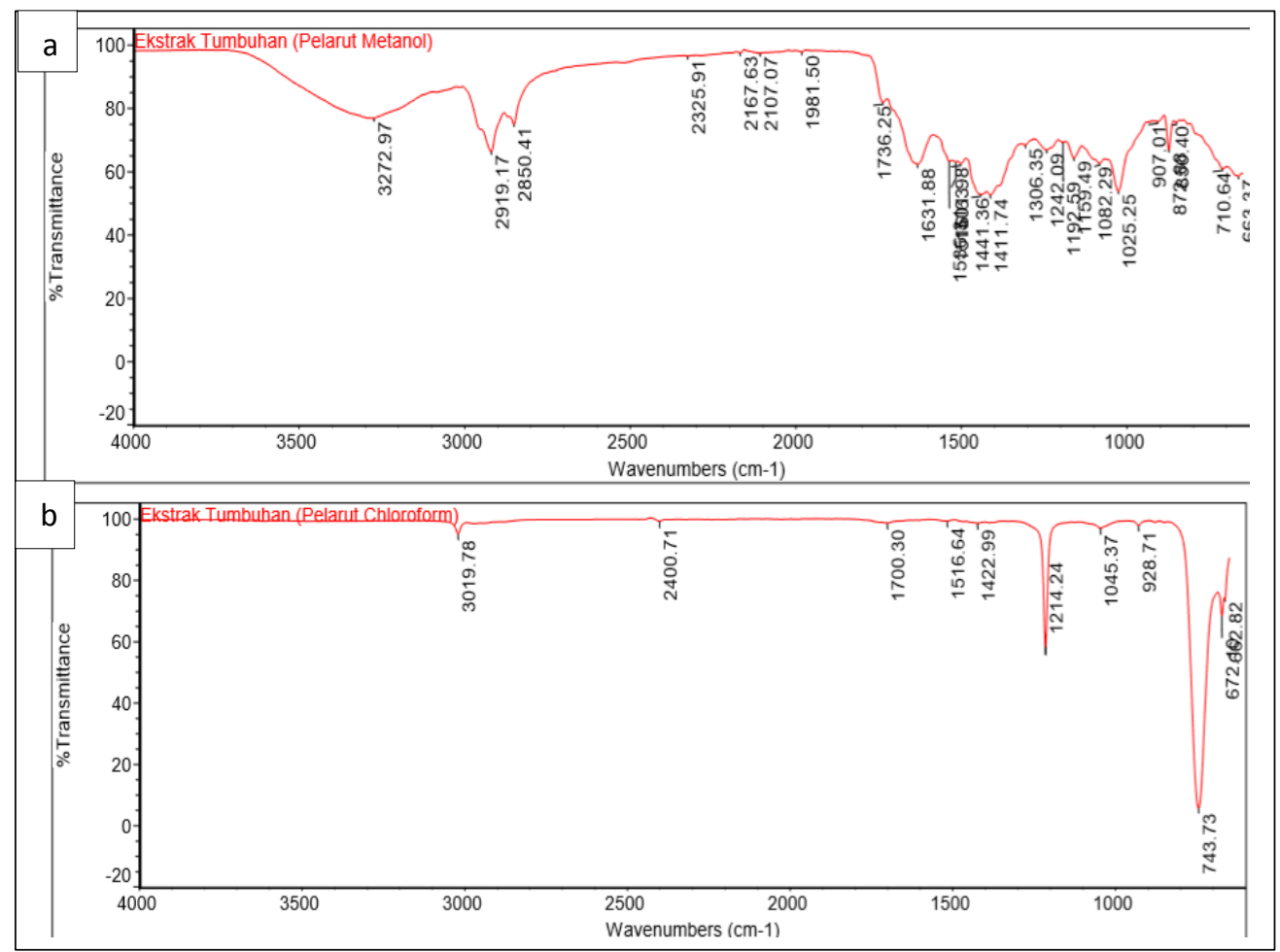

Gambar 1. Spektra FTIR (a) Fraksi Metanol (b) Fraksi Kloroform

Spektra inframerah fraksi metanol daun Lavetar menunjukkan adanya pita serapan pada bilangan gelombang $3272,97 \mathrm{~cm}^{-1}$ yang merupakan serapan $\mathrm{C}-\mathrm{H}$ streching aromatik yang didukung oleh adanya serapan $\mathrm{C}=\mathrm{C}$ aromatik pada bilangan gelombang 1631,88 - 1411,74 $\mathrm{cm}^{-1}$. Pita serapan pada panjang gelombang 2919,17 - 2850,41 $\mathrm{cm}^{-1}$ menunjukkan adanya serapan $\mathrm{C}-\mathrm{H}$ stretchcing alifatik. Pita serapan pada bilangan gelombang $1736,25 \mathrm{~cm}^{-1}$ menunjukkan adanya serapan $\mathrm{C}=\mathrm{O}$ yang didukung oleh adanya.serapan $\mathrm{C}-\mathrm{O}$ stretching pada daerah bilangan gelombang 1159,49 - 1025,25 $\mathrm{cm}^{-1}$. Hasil interpretasi spektra FTIR fraksi metanol daun Lavetar diduga mengandung senyawa flavanoid, hal ini didukung oleh hasil skrining fitokimia yang menunjukkan bahwa fraksi metanol daun Lavetar positif kuat mengandung senyawa flavanoid.

Hasil interpretasi spektra FTIR fraksi kloroform menunjukkan adanya pita serapan pada daerah bilangan gelombang $3019,78 \mathrm{~cm}^{-1} \quad$ yang merupakan daerah serapan $=\mathrm{C}-\mathrm{H}$ stretching aromatik yang didukung oleh adanya pita serapan kuat dari $\mathrm{C}-\mathrm{H}$ bending pada daerah bilangan gelombang $743,73 \mathrm{~cm}^{-1}$. Pita serapan pada bilangan gelombang $1214,64 \mathrm{~cm}^{-1}$ adalah regangan $\mathrm{C}-\mathrm{O}$ yang merupakan serapan khas untuk senyawa eter (Silversten et al., 1991; Bakkialakshmi, S., Roy, J, 2017).

\section{Hasil Analisis GC-MS}

Hasil analisis GC-MS, kromatogram fraksi metanol terlihat 84 komponen senyawa, yang dapat dilihat pada Gambar 2. 

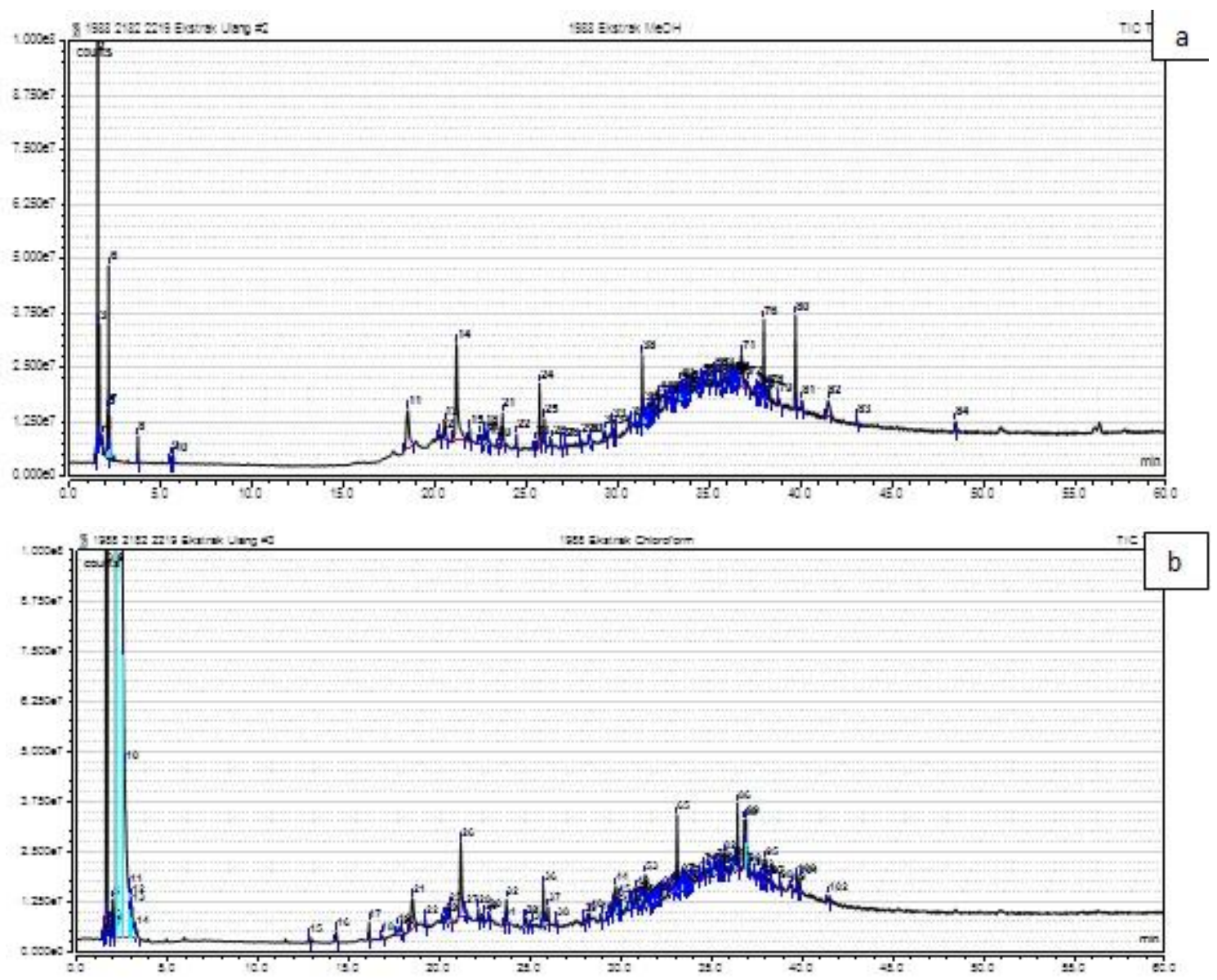

Gambar 2. Kromatogram GC-MS (a) Fraksi Metanol (b) Fraksi Kloroform

Hasil analisis kromatogram didapatkan beberapa komponen senyawa tertinggi fraksi Metanol yaitu pada puncak 80 sebesar $3,90 \%$ dengan memiliki berat molekul 243,2. Jika dibandingkan dengan data library memiliki Indeks Kemiripan (SI) yaitu $82,1 \%$ terhadap spektra senyawa 1 Heptatriacotanol yang didukung pada pola fragmentasi sehingga dapat diperkirakan bahwa puncak 80 merupakan senyawa 1-Heptatriacotanol. Senyawa tertinggi kedua yaitu pada puncak 71 sebesar 3,34 \% dengan memiliki berat molekul 123,1. Jika dibandingkan dengan data library memiliki Indeks Kemiripan (SI) yaitu $77,8 \%$ terhadap spektra senyawa Phytol yang didukung pada pola fragmentasi sehingga dapat diperkirakan bahwa puncak 71 merupakan senyawa Phytol. Senyawa tertinggi ketiga yaitu pada puncak 38 sebesar 3,29\% dengan memiliki berat molekul 109,1. Jika dibandingkan dengan data library memiliki Indeks Kemiripan (SI) 82,8\% yaitu terhadap spektra senyawa Neophytadiene yang didukung pada pola fragmentasi sehingga dapat diperkirakan bahwa puncak 38 merupakan senyawa Neophytadiene. Senyawa tertinggi keempat yaitu pada puncak 76 sebesar $3,19 \%$ dengan memiliki berat molekul 
159,1. Jika dibandingkan dengan data library memiliki Indeks Kemiripan (SI) $76,2 \%$ yaitu terhadap spektra senyawa 1-Heptatriacotanol yang didukung pada pola fragmentasi sehingga dapat diperkirakan bahwa puncak 76 merupakan senyawa 1Heptatriacotanol.

Hasil analisis GC-MS, kromatogram fraksi Kloroform terlihat 102 komponen senyawa. Dari hasil analisis kromatogram diperoleh beberapa komponen senyawa tertinggi fraksi kloroform yaitu pada puncak 65 sebesar $0,14 \%$ dengan berat molekul 143,1. Jika dibandingkan dengan data data library memiliki Indeks Kemiripan (SI) yaitu 78,5 \% terhadap spektra senyawa Cyclopropanebutanoic acid, 2[[2-[[2-[(2pentylcyclopropyl)methyl]cyclopropyl] methyl]cyclopropyl]methyl]-methyl ester yang didukung pada pola fragmentasi sehingga dapat diperkirakan bahwa puncak 65 merupakan senyawa Cyclopropanebutanoic acid, 2-[[2-[[2[(2-pentylcyclopropyl)

methyl]cyclopropyl] methyl] cyclopropyl] methyl] - methyl ester. Senyawa tertinggi kedua yaitu pada puncak 36 sebesar $0,11 \%$ dengan memiliki berat molekul 142,2. Jika dibandingkan dengan data library memiliki Indeks Kemiripan (SI) yaitu $73,4 \%$ terhadap spektra senyawa 1Octanamine, n-octyl yang didukung pada pola fragmentasi sehingga dapat diperkirakan bahwa puncak 36 merupakan senyawa 1-Octanamine, noctyl. Senyawa tertinggi ketiga yaitu pada puncak 12 sebesar $0,07 \%$ dengan memiliki berat molekul 173,9. Jika dibandingkan dengan data library memiliki Indeks Kemiripan (SI) yaitu $64,0 \%$ terhadap spektra senyawa Tricholormethane yang didukung pada pola fragmentasi sehingga dapat diperkirakan bahwa puncak 12 merupakan senyawa Tricholormethane. Senyawa tertinggi keempat yaitu pada puncak 17 sebesar $0,03 \%$ dengan memiliki berat molekul 150,2. Jika dibandingkan dengan data library memiliki Indeks Kemiripan (SI) yaitu $80,6 \%$ terhadap spektra senyawa DVerbenone yang didukung pada pola fragmentasi sehingga dapat diperkirakan bahwa puncak 17 merupakan senyawa D-Verbenone. Senyawa tertinggi kelima yaitu pada puncak 16 sebesar $0,02 \%$ dengan memiliki berat molekul 109,1. Jika dibandingkan dengan data library memiliki Indeks Kemiripan (SI) yaitu $79,8 \%$ terhadap spektra senyawa transVerbenol yang didukung pada pola fragmentasi sehingga dapat diperkirakan bahwa puncak 16 merupakan senyawa trans-Verbenol.

\section{Uji Aktivitas Penghambatan enzim $\alpha-$ Glukosidase}

Uji aktivitas penghambatan enzim $\alpha$-Glukosidase fraksi methanol dan fraksi kloroform disajikan pada Gambar 2. 


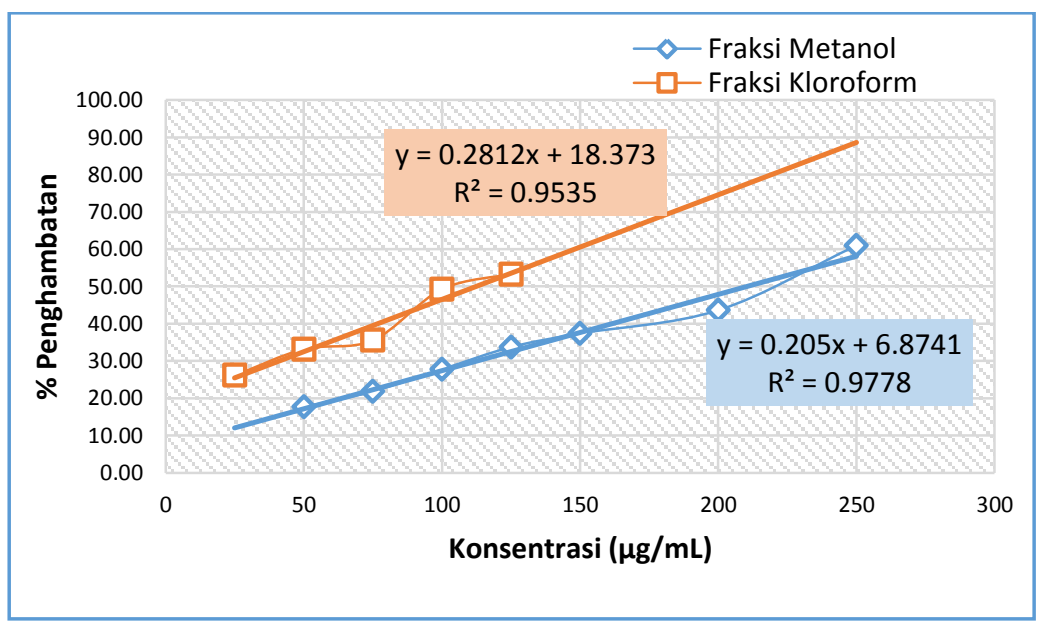

Gambar 2. Kurva hubungan \% penghambatan dengan konsentrasi sampel

\section{Nilai $\quad \mathrm{IC}_{50} \quad$ (Inhibitory}

Concentration) ditentukan berdasarkan kurva hubungan antara \% penghambatan dengan konsentrasi sampel dan diperoleh persamaan regresi linear untuk fraksi methanol dan fraksi kloroform masing-masing adalah $\mathrm{y}=0,205 \mathrm{x}+$ 6,8741 dan $y=0,2812 x+18,373$ (Gambar 2). Hasil perhitungan $\mathrm{IC}_{50}$ dengan menggunakan persamaan (2), nilai $\mathrm{IC}_{50}$ untuk fraksi methanol dan fraksi kloroform daun Lavetar masingmasing sebesar 211,151 $\mu \mathrm{g} / \mathrm{mL}$ dan 112,562 $\mu \mathrm{g} / \mathrm{mL}$ (Tabel 2).

Tabel 2. Nilai $\mathrm{IC}_{50}$ dan aktivitas antidiabetes fraksi methanol dan fraksi kloroform

\begin{tabular}{ccc}
\hline Fraksi & $\begin{array}{c}\mathbf{I C}_{\mathbf{5 0}} \\
(\boldsymbol{\mu g} / \mathbf{m L})\end{array}$ & Kategori \\
\hline Metanol & 211,15 & Sangat lemah \\
Kloroform & 112,56 & Lemah \\
\hline
\end{tabular}

Nilai $\mathrm{IC}_{50}$ fraksi kloroform daun lavetar lebih kecil daripada fraksi metanol daun lavetar, hal ini menunjukkan bahwa aktivitas penghambatan $\alpha$-glukosidase fraksi kloroform lebih besar daripada fraksi metanol daun lavetar. Mardawati et al., (2008) menyatakan bahwa $\mathrm{IC}_{50}<50$ $\mu \mathrm{g} / \mathrm{mL}$ tergolong sangat kuat, jika $50-$ $100 \mu \mathrm{g} / \mathrm{mL}$ tergolong sedang, jika $\mathrm{IC}_{50}$ bernilai $\quad 100 \quad-150 \mu \mathrm{g} / \mathrm{mL}$ tergolong lemah, dan sangat lemah jika nilai $\mathrm{IC}_{50}>$ $200 \mu \mathrm{g} / \mathrm{mL}$. Berdasarkan klasifikasi tersebut, maka aktivitas penghambatan fraksi kloroform tergolong lemah, sedangakan fraksi metanol tergolong sangat rendah. 


\section{KESIMPULAN}

Hasil skrining fitokimia menunjukkan bahwa senyawa aktif pada fraksi metanol adalah flavonoid dan tannin sedangkan fraksi kloroform mengandung senyawa flavonoid, tannin, dan saponin. Uji aktivitas penghambatan enzim $\alpha$-glukosidase fraksi kloroform tergolong lemah sedangkan fraksi metanol tergolong sangat lemah dengan nilai nilai $\mathrm{IC}_{50}$ masing - masing sebesar $112,562 \mu \mathrm{g} / \mathrm{mL}$ dan $211,151 \mu \mathrm{g} / \mathrm{mL}$. Hasil Interpretasi spektra FTIR dan skrining fitokimia menunjukkan bahwa gugus fungsi utama adalah flavanoid. Hasil analisis dengan GC-MS menunjukkan bahwa pada fraksi metanol terdapat 84 puncak senyawa dengan senyawa dominan yaitu 1Heptatriacotanol $(\mathrm{m} / \mathrm{z}=190)$ dan fraksi kloroform terdapat 102 puncak senyawa dengan senyawa dominan yaitu cyclopropanebutanoic acid,2-[[2-[[2-[(2pentylcyclopropyl)methyl]cyclopropyl] metyl]-,metyl ester $(\mathrm{m} / \mathrm{z}=270)$.

\section{DAFTAR PUSTAKA}

Anonim, 2016. Diabetes Fakta dan Angka. Available from: http://www.searo.who.int/. Oktober 2018].

Bakkialakshmi., Roy, J., 2017. Infared Spectrum Analysis of Some Flavanoid with Hemoglobin, Internasional Journal of Appiled and Advanced Scienitific Reaserch, volume 2, Issue 2, Page Number 107-110.

Corwin, E.J., 2000. Handbook of Pathophysiology, $\quad 2^{\text {nd }} \quad$ ed., Lippincott, New York, 573.

Harbone, J. B., 1987. Metode Fitokimia. Penuntun Cara Modern Menganalisis Tumbuhan 2. ITB. Bandung.

McDougall, G.J.; Shpiro, F.; Dobson, P.; Smith, P.; Blake, A.; Stewart, D. Different polyphenolic components of soft fruits inhibit $\alpha$-amylase and $\alpha$-glucosidase. Journal of Agricultural and Food Chemistry 2005, 53, 2760-2766

Silverstein, R. M., Bassler, G.B., dan Morril, $\quad$ T.C., 1991. Spectrometric Indentification of Organic Coumpounds. John Wiley, New York, pp.109-130. 